\title{
The effectiveness of Tai Chi exercises on the mental health of women with breast cancer
}

\section{Solmaz Babaei Bonab ${ }^{1}$}

1-Assistant professor, Department of Sports Sciences, University of Maragheh, Maragheh, Iran (Corresponding Author).

E-mail: s.babaei@maragheh.ac.ir

Received: 23/02/2020
Accepted: 15/04/2020

\begin{abstract}
Introduction: Breast cancer is one of the most common and fatal types of cancer which affects women more emotionally and psychologically than other types.

Aim: The aim of this study was to investigate the effectiveness of Tai Chi exercises on the mental health of women with breast cancer.

Method: A pre-test post-test design with control group was used in this quasi-experimental study in 2019. Samples of the study were women with breast cancer in Urmia. A total of 30 women were selected through convenient sampling (15 control group and 15 training group). The training group participated in a 12 weeks physical training (Tai Chi exercises) with average intensity of 55-70 percent for 60 minutes three days a week. General Health Questionnaire (Goldberg \& Hiller, 1979) was used in this study. The results were analyzed via covariance analysis in SPSS 20 software.

Results: The results indicated that after 12 weeks of Tai Chi exercises, general health subscale scores of physical $(\mathrm{p}<0.01)$, anxiety and insomnia $(\mathrm{p}=0.01)$, social dysfunction $(\mathrm{p}<0.01)$, and depression $(\mathrm{p}=0.01)$ significantly decreased in the training group compared to the control group $(\mathrm{p}<0.05)$.
\end{abstract}

Conclusion: The results showed that Tai Chi exercises can improve mental health in women with breast cancer.

Keywords: Breast cancer, Mental health, Tai Chi exercises

How to cite this article : Babaei Bonab S. The effectiveness of Tai Chi exercises on the mental health of women with breast cancer. Shenakht Journal of Psychology and Psychiatry. 2020; 7 (2): 79-90 .URL: http://shenakht.muk.ac.ir/article-1-898-fa.pdf

Copyright ( 2018 the Author (s). Published by Kurdistan University of Medical Sciences. This is an open access article distributed under the terms of the Creative Commons Attribution-Non Commercial License 4.0 (CCBY-NC), where it is permissible to download, share, remix, transform, and buildup the work provided it is properly cited. The work cannot be used commercially without permission from the journal. 


\section{اثربخشى تمرينات تاى جى بر سلامت روان زنان مبتلا به سرطان بستان}

سولماز بابايیى بناب' ا.استاديار، كروه علوم ورزشى، دانشكاه مراغه، مراغه، ايران (مولف مسئول). ايميل: s.babaei@ maragheh.ac.ir

مقدمه: سرطان بستان يكى از شايعترين و برتلفات ترين سرطانها بوده و از نقطه نظر عاطفى و روانى بيش از ساير سرطانها زنان را تحت تأثير قرار مىدهد. هدف: هدف از يُوهش حاضر بررسى اثربخشى تمرينات تاىجى بر سلامت روان زنان مبتلا به سرطان بِستان بود. روش: يثوهش حاضر از نوع نيمه تجربى با طرح بيش آزمون-بس آزمون با گروه شاهد در سال يوها اجرا شد. جامعه آمارى اين

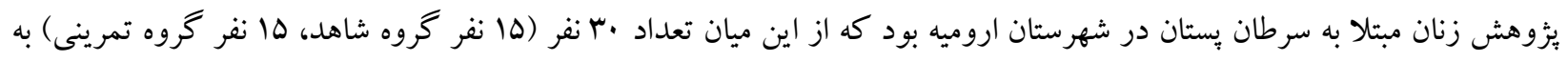

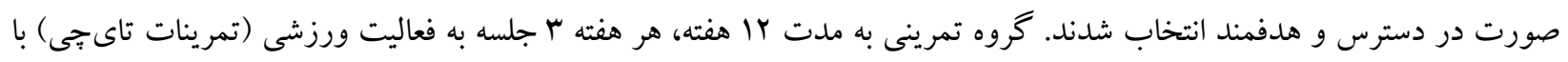

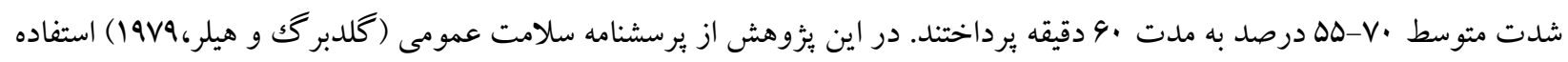
شد. نتايج با استفاده از تحليل كوواريانس با نرم افزار · rspss تحليل شدند.

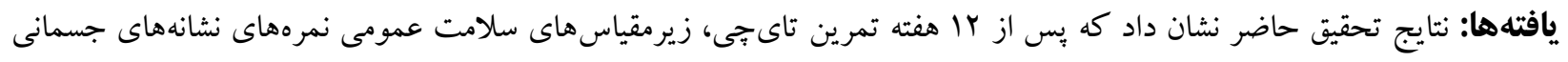

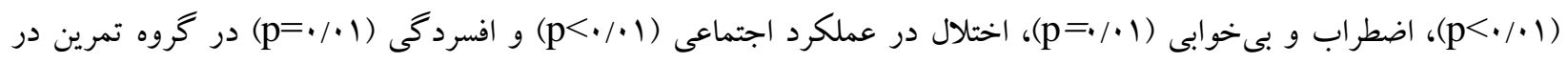

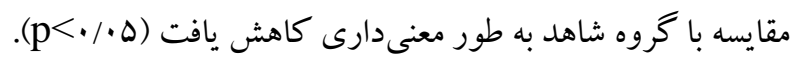
نتيجه كيرى: نتايج مطالعهى حاضر نشان مىدهد كه انجام تمرينات تاى پى مىتواند سلامت روان را در زنان مبتلا به سرطان پِتان بهبود بخشد. كليدوازهها: سرطان يֶتان، سلامت روان، تمرينات تاىجى 
مشكلاتى در بر گشت به زندگى عادىشان مىشود. نتيجه

مقدمه

برخى از مطالعات نشان دادهاند كه فعاليت بدنى يكى از سرطان بِتان شايعترين نوع سرطان زنان در سراسر جهان فاكتورهاى اساسى در بر گشت به زند گیى عادى افراد مبتلا به سرطان است (اسميت، برو كس، كو كونيدس، ساسلو و

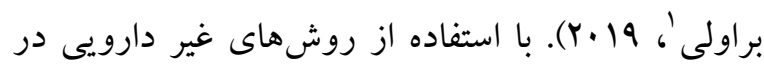
درمان مشكلات روانى بيماران مبتلا به سرطان كه خود تحت درمان دارويى مىباشند، به عنوان روش طب مكمل استفاده مىشود. يكى از انواع طب مكمل، طب ذهن بدن است كه طراحى آن به گونهاى است كه توانايى ذهن را براى تحت تأثير قرار دادن عملكرد بدن افزايش مىدهند كه ورزش تاى جى جوان در اين گروه قرار دارد

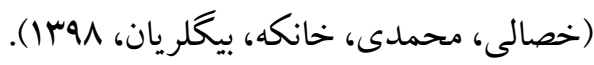

در اين ميان ورزش تاىجى كه ورزشى جسمى و روحى است، با انجام حر كات نرم و آرام، زمينه را براى افزايش فعاليت ذهنى، بهبود فعاليت قلب و ... مهيا مى كند (مرندى، رضايت، اسفرجانى و رضايى، بوسا). تاىجى يكك هنر رزمى باستانى جينى است كه با حركات كنترل شده آرام، نفس عميق آرام و وضعيت بدنى صحيح همراه با حالت آكاهى و تمركز نمايش داده مىشود و مجموعهاى از حركات جسمى، تكنيككهاى تنفسى و ابزار ادراكى بينايى، آكاهى متمر كز درونى براى تقويت بدن، آرامش جسم و ذهن استفاده مىشود (عظيم زاده، حسينى، نوروزى تبريزى، بوس|). تركيب اجراى جسمانى و شناختى در تاىجى مىتواند ارزش بيشتر آن را در مقايسه با ديخر برنامهاى ورزشى كه تنها متمركز بر جنبهى جسمانى است، آشكار سازد (لو گل، ورهاگن،

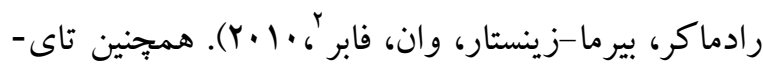
جّى با تحريكك اعصاب باراسمياتيك، سبب افزايش نشاط

1 - Smite, Brooks, Cokkindes, Saslow, Brawley

2. Logghe, Verhagen,Rademaker, Bierma-Zeinstra, van Rossum, Faber 
در هر دو گروه ارتباطى نداشت؛ به هر حال با بهبود عملكرد اجتماعى در ميان گروه نجات يافته بعد از درمان كه عملكرد اجتماعى كمى را در ابتداى تحقيق گزارش كرده بودند، مرتبط بود (راك، دويل، دماركك،

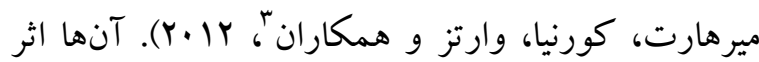
سودمندى تمرين در دورههاى كوتاهمدت و بلافاصله بعد از دوره درمان را مورد تأكيد و همجنين به مزيت مداخلات تمرين و فعاليت بدنى در دورههاى طولانى

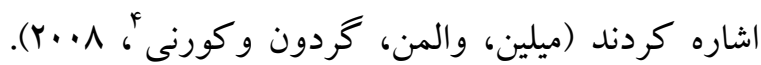
شواهد نشان مىدهد كه در حال حاضر افزايش رفتارهاى بى تحر كك به همر اه سطوح بايين فعاليت با كيفيت زندكى و تركيب بدنى هايين در ارتباط است و باعث افزايش

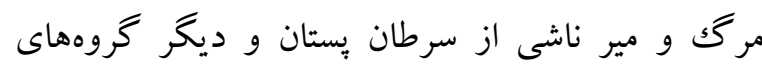
نجات يافته از سرطان مىشود (لنج، دانستان و والنسهُ

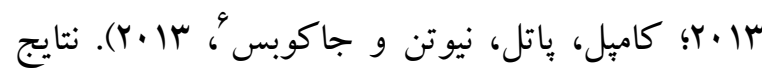
مطالعهى مكفارلند نشان داد كه ورزش تاىجى جوان سبب بهبود عملكرد جسمى و روانى زن سالمند مى گردد

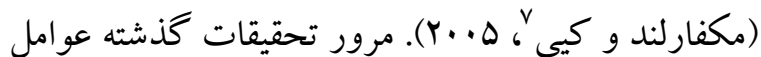
دخيل در سلامتى افراد بيمار را بس از يكك دوره فعاليت بدنى نشان مىدهد با اين حال اثر فعاليت بلدنى منظم در زنان مبتلا به سرطان يّتان يّ از تشخيص آن، هنوز هم موضوع بحث در تحقيقات سرطان است (فونتئن، گلاس،

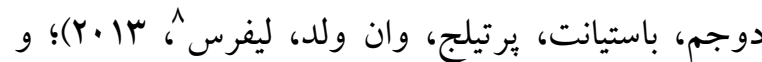
مىتوان كفت با وجود افزايش تعداد بيماران مبتلا به سرطان بِتان، مطالعه در زمينه سلامت روان اين افراد محدود مىباشد. با توجه به اهميت موضوع، در كل هدف

${ }^{3}$ - Rock,Doyle, Demark-Wahnefried, Meyerhardt, Courneya, Schwartz,et al

${ }^{4}$ - Milne, Wallman, Gordon, Courneya

5 - Lynch Dunstan, Vallance

${ }^{6}$ - Campbell,patel, newton,Jacobs

7. Macfarlen,kee

${ }^{8}$ - Fontein,glas,duijm,bastiaannet,protielje,van velde,liefers
و آرامش روحى، افزايش تمركز و اراده و دور شدن افكار بريشان مىشود. در بين انواع سبك هاى تاىجى، سبك تاى بجى جوان داراى حر كات نرمتر، يكنو اخت تر و فاقد حركات انفجارى و شديد است و اجراى آن توصيه مىشود (مرندى و همكاران، ץوبا). انجام تمرينات تاىجى جوان باعث افز ايش F م درصدى فعاليت باراسمياتيك شده است و كاهش با درصدى فعاليت سمباتيكك و در نتيجه افزايش آرامش در زنان بيمار مىشود (آدوت،

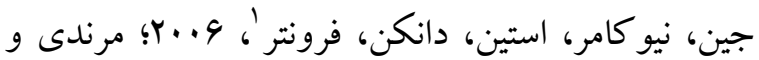
همكاران، rara). انجام اين ورزش به طور منظم با تقويت عملكرد قلبى و تنفسى، عزت نفس، سلامت روان و تعاملات اجتماعى همراه است، تمرين منظم تاى :جى در سال هاى اخير براى افراد با بيمارىهاى مختلف توصيه شده است (نومرا، ناكونا، تاكاتو، يوكى، ماتسوزاكى،

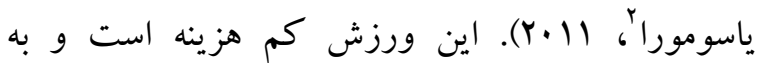
تجهيزات خاص ورزشى نياز ندارد و حتى زنان مبتلا به سرطان بِتان كه دامنهى حر كتى دستشان كمتر قابل اجرا مى شود (مرندى و همكاران، بوسا) و در جندين مطالعه تأثير مثبتى بر كيفيت زندكى افراد مختلف و مبتلايان به بيمارى سرطان، آرتريت روماتئيد، بيماران ام اس و ديابت

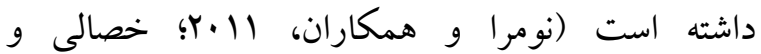
همكاران، وهبا). •ه آزمودنى كه سرطان يستان آنها اخيراً تشخيص داده شده بود در طول يكك دوره 4 ماهه شركت كردند. اين آزمودنىها به طور مساوى به دو كروه تقسيم شدند كه يك گروه تمرينات ورزشى در

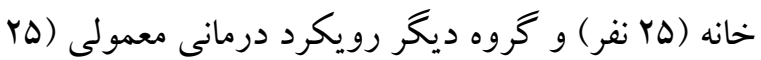
نفر ) داشتند؛ نتايج نشان داد كه كيفيت زندگى در هر دو

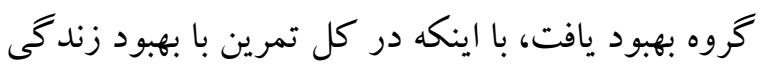

\footnotetext{
1- Audette, Jin, Newcomer, Stein, Duncan, Frontera

${ }^{2}$ - Nomura, Nagano, Takato, Uekis, Matsuzaki, Yasumura
} 
يُؤهش حاضر براى تجزيه و تحليل دادههاى به دست از روشهاى آمار توصيفى مانند شاخصهاى ميانكين و و انحراف استاندارد و آمار استنباطى، از آزمون آمارى تحليل كوواريانس استفاده شد. تحليل دادهها با استفاده از نسخهى •r نرم افزار آمارى spss انجام شد.

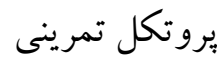
كروه تمرينى به مدت برو الهفته و هر هفته ب جلسه و هر جلسه به مدت •9 دقيقه در روزهاى زوج ساعت 9 الى •ا صبح طبق برنامه ارائه شده فعاليت تمرينى تاىجى انجام دادند تمام برنامه تمرينى در مركز تندرستى دانشگاه اروميه انجام شد. تمرينات تاىجى به صورت آموزش بـ لهر اجراى حركات اصلى و تمرينات تعادلى ورزشى تاى-

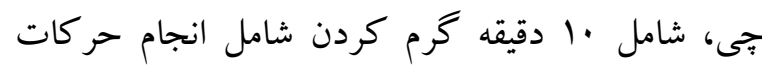
جرخاندن شانه، جرخاندن سر به طرفين و حركات جمباتمه، ·F دقيقه تمرينات تاىجى كه به شيوهاى آرام و بدون هيج وقفهاى در اجر اى حر كات به صورت فرمهاى

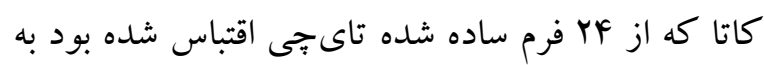
همراه تنفس عميق و كنترل شده و ·ا دقيقه تمرينات بر گشت به حالت اوليه توسط مربى انجام شد (نوروزيان، رجبى و يناه زاده، צوب1). در هفتهى اول، برنامه تمرينى

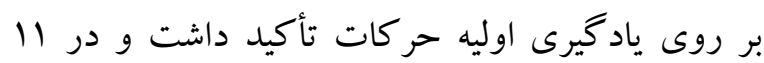
هفتهى باقىمانده براى افزايش عملكرد حر كتى و تعادل، تمركز بر انجام فردى حر كات بود. موسيقى مخصوص

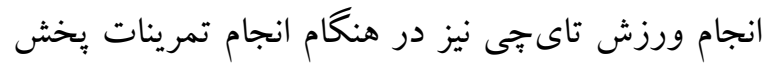
شد. در طول تمرين به شركت كنند گان اجازه داده شد تا براى دورههاى استراحت كوتاه مدت روى صندلى بنشيند. در مدت مداخله تمرينى گروه شاهد هيج گونه تمرين ورزشى دريافت نكردند. همجنين در مدت اين
يثزوهش حاضر تعيين اثربخشى Yl هفته تمرين تاى بى بر سلامت روان زنان مبتلا به سرطان يستان در شهرستان

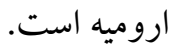

\section{روش} روش يثوهش حاضر نيمه تجربى بوده و در قالب طرح بيش آزمون-بِ آزمون با كرووه شاهد و تمرينى اجرا شد. جامعهى آمارى يُزوهش شامل تمام زنان مبتلا به سرطان بستان مراجعه كننده به مركز درمانى شهرستان اروميه بود كه از بين ·f نفر زن مبتلا به سرطان بِ بستان كه از شرايط مساوى در سن، بيمارى، طول دوره درمان و روش درمان برخوردار بودند ·• زمن مبتلا به سرطان يستان انتخاب و و

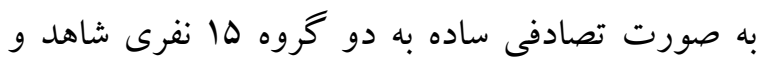
تمرينى تخصيص يافتند. معيارهاى ورود به مطالعه شامل: زنان مبتلا به سرطان يستان، بازهى سنى ذه-هأ، عدم ابتلا به بيمارىهاى حاد يا مزمن ناتوان كننده، عدم ابتلا به بيمارىهاى مزمن (آريتمى كنترل نشده، برفشار خونى و ديابت)، همجنين عدم شركت در فعاليتهاى ورزشى منظم در طى 9 ماه گذشته بود. معيار خروج از مطالعه عبارت بود از غيبت بيش از يكك جلسه در برنامه ورزشى، عود بيمارى، بروز حادثه، تشخيص يزشك معالج، آسيب فيزيكى، عدم تمايل به ادامه همكارى و بروز هر عامل

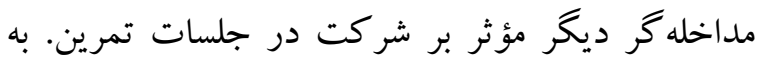
شركت كنند گان اطمينان داده شد كه در هر مرحله از تحقيق مى تواند از مطالعه خارج شوند هميخنين اطلاعات آنها محرمانه باقى خواهد ماند. آزمودنى ها قبل و بعد از r إ هفته مداخله به منظور ير كردن يرسشنامه ها فراخوانده شدند.). يرسشنامه در قبل از شروع برنامه تمرينى و در آخر برنامه تمرينى توسط آزمودنىها تكميل گرديد. در 
كمترين حد با نمره كل از صفر تا YY) و يا نمره ناسالم (در يكى از سه حيطه اختلال خفيف، متوسط و يا شديد با نمره كل بيش از YY) قرار خواهد گرفت (رشيدى، يورنجف، كاظمى و كيخاونى، IIIVV). روايى و يايايى به دست آمده از تحقيق كلدبر گك براى خرده مقياس علائم

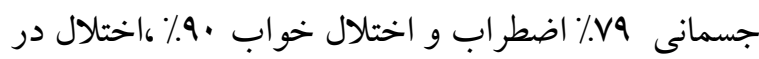
عملكرد اجتماعى VD٪ و براى افسردكى 99٪ كز ارش شد

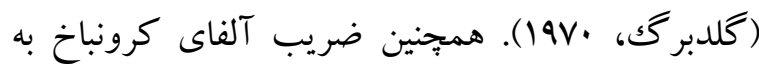
دست آمده در بززوهش رشيدى و همكاران در مقايس هاى علائم جسمانى، اضطراب و اختلال خواب، اختلال در عملكرد اجتماعى و افسردگى و همجينين نمرهى كل إنى

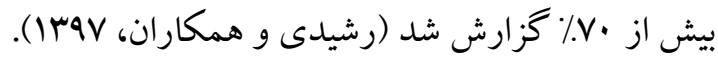

\section{يافتهها}

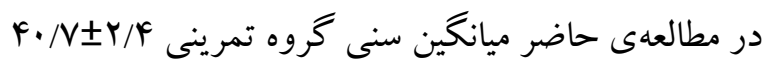
و ميانگين سنى گروه شاهد

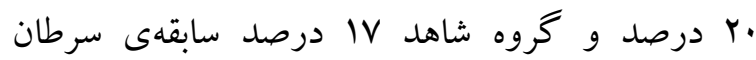
خانوادگى داشتند. مدت ابتلا به بيمارى سرطان در گرووه تمرينى ها ماه و گروه شاهد بr ماه بود. ها نفر از گرووه تمرينى و 9 نفر از گروه شاهد مجرد و ·.ا نفر از كروه تمرينى و q نفر از گروه شاهد متأهل بودند. از گرووه تمرينى 9 درصد شيمىدرمانى داشته، 11 درصد تحت درمان جراحى بودند و \&r درصد از گروه تمرينى تحت جراحى قراركرفته و شيمى درمانى شده بودند و از گروه شاهد Y I درصد تحت شيمىدرمانى بودند، ال درصد عمل جراحى انجام داده بودند و 19 درصد تحت عمل جراحى قرار گرفته و شيمى درمانى شده بودند. تفاوت معنى دارى در ميانگين نمرات سلامت روان گروه تمرين و گروه شاهد قبل از مداخله وجود نداشت (1991/. >p).
هفته از خروههاى تمرينى و شاهد خواسته شد به درمان دارويى قبلى خود ادامه دهند.

ابز ار يرسشنامه سلامت عمومى GHQ-28. برسشنامه سلامت عمومى كه توسط كلدبرگك و هيلر' (9V9) ساخته و معرفى گرديده است. اين برسشنامه يكى از ابزارهايى است كه به طور گسترده در بين ابزارهاى سلامت روان در زمينه بررسى كيفيت روان سنجى مورد استفاده قرار مى گيرد. اين يرسشنامه شامل rA سؤال است كه دربر گيرندهى \& مقياس شامل علائم جسمانى، اضطراب و ولم اختلال خواب، اختلال در عملكرد اجتماعى و مقياس افسردگى است و به بررسى وضعيت روانى فرد در يك ماهه اخير مى بردازد و شامل نشانههايى مانند افكار و احساسات نابهنجار و جنبههايى از رفتار قابل مشاهده است

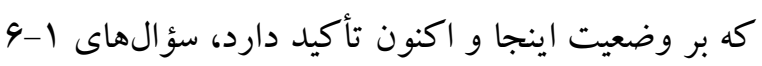
و سؤال 19 مربوط به مقياس علائم جسمانى، سؤالهاى V-Ir مربوط به مقياس علائم اضطرابى و اختلال در خواب، سؤالهاى YF

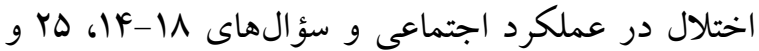
צr مربوط به مقياس علائم افسردگى است. در اين مطالعه از شيوه نمره گذارى ليكرت به منظور نمره گذارى يرسشنامه استفاده شد و هر يكك از سؤالات به صورت

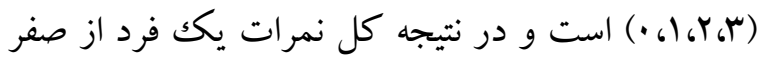
تا NF متغير خواهد بود كه نمره كمتر بيانگر بهداشت روانى بهتر و بالاتر بالعكس است. بر اساس برسشنامه

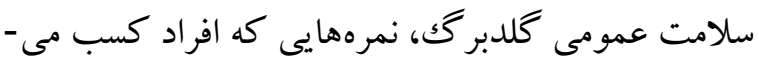
كنند در يكى از دو حيطه نمره سالم (اختلال هيج يا

1. Goldberg \& hilder 
تمرينات تاىجى سبب افزايش سلامت روانى زنان مبتلا به سرطان مىشود تائيد مى گردد. جدول ا مقايسهى ميانگين سلامت روان را در دو گروه تمرينى و شاهد در دو مرحلهى بيش آزمون و بِ آزمون نشان مىدهد.
پس از اجراى يروتكل تمرينى اين تفاوت معنىدار شد

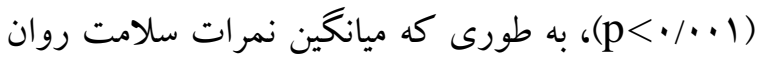
در گروه تمرينى در بس آزمون بيشتر از گروه شاهد بود.

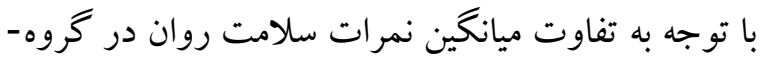
ها در بيش آزمون و پِس آزمون، اين فرضيه كه انجام

جدول ا مقايسه ميانكين سلامت روان دو گروه تمرينى و شاهد

\begin{tabular}{|c|c|c|c|c|c|c|}
\hline \multirow[t]{2}{*}{ معنادارى } & \multicolumn{2}{|c|}{ يس آزمون } & \multicolumn{2}{|c|}{ يِيش آزمون } & \multirow[t]{2}{*}{ تعداد } & \multirow[t]{2}{*}{ كروه } \\
\hline & انحراف معيار & ميانگين & انحراف معيار & ميانگين & & \\
\hline$\cdot / \cdot \cdot 1$ & $Q M / T F$ & $\mid r / \cdot V$ & AV/Ir & $\Lambda / \Delta F$ & 10 & تمرين \\
\hline$\cdot / \Delta \Lambda \mid$ & $\Delta 1 / 1 \mu$ & N/VG & $G F / T M$ & N/9. & 10 & شاهد \\
\hline & $\cdot / \cdots 1$ & & & $\cdot / M F \mid$ & & معنادارى \\
\hline
\end{tabular}

انحراف معيار سلامت روان در مؤلفهاى نشانهاى جسمانى، اضطراب و بىخوابى، اختلال در عملكرد اجتماعى و افسردگى در دو گروه تمرينى و شاهد در دو مرحلهى بيش آزمون و پِ آزمون نشان داده شده است.
جدول ا نشان مىدهد كه ميانگين نمرات ييش آزمون كروه تمرينى و گروه شاهد اختلاف معنى آدارى ندارد؛ اما ميانگين نمرات بس آزمون گُروه تمرينى از ميانگين نمرات گرووه شاهد كمتر است. در جدول r ميانگين و

جدول r ميانكين و انحراف معيار سلامت روان تروههاى تمرينى و شاهد در يِش آزمون و يس آزمون

\begin{tabular}{|c|c|c|c|c|c|c|}
\hline \multicolumn{2}{|c|}{ يس آزمون } & \multicolumn{2}{|c|}{ ي يش آزمون } & \multirow[t]{2}{*}{ تعداد } & \multirow[t]{2}{*}{ متغير ها } & \multirow[t]{2}{*}{ كروه } \\
\hline انحر اف معيار & ميانگين & انحر اف معيار & ميانگين & & & \\
\hline $9 / 1$ & $\Delta / r \mu$ & F/Fr & $9 / \wedge$ & 10 & ن شانه هاى جسمانى & تمرينى \\
\hline $11 / r$ & $9 / 40$ & r/ar & $11 / r$ & 10 & اضطراب و بىخو ابى & \\
\hline $1 r / 9$ & $\Lambda / r$ & $9 \pi / \Delta$ & $1 \% / 9$ & 10 & اختلال در عملكرد اجتماعى & \\
\hline$\Lambda / \mu$ & $r / \Delta$ & $\Delta / \cdot r$ & $\Lambda / r$ & 10 & افسردگى & \\
\hline$V / 9 \Delta$ & $9 / \Delta 9$ & $\Lambda / \Upsilon \wedge$ & $9 / 9 \Lambda$ & 10 & نشانه هاى جسمانى & شاهد \\
\hline $1 \cdot / 44$ & $11 / \cdot 0$ & $\Delta / V \Delta$ & $1 \cdot / 91$ & 10 & اضطر اب و بىخوابى & \\
\hline $1 F / V q$ & $1 r / 99$ & Ir/VD & $1 r / \cdot r$ & 10 & اختلال در عملكرد اجتماعى & \\
\hline$V / 9$ & $\mathrm{~V} / \mathrm{\Lambda}$ & $F / F q$ & $\Lambda / Y \Lambda$ & 10 & افسردگى & \\
\hline
\end{tabular}

مؤلفه ها نسبت به بيش آزمون تغيير جندانى نداشته است. جدول ب نتايج تحليل كوواريانس از مقايسه نمرات يس آزمون گروه تمرينى با گرووه شاهد بر مؤلفههاى
جدول Y نشان مى دهد كه نمرات مؤلفههاى سلامت روان در بس آزمون گرووه تمرينى نسبت به بيش آزمون كاهش داشته است، همجنين در گرووه شاهد نمرات يس آزمون 
نشانهاى جسمانى، اضطراب و بىخوابى، اختلال در مىدهد.

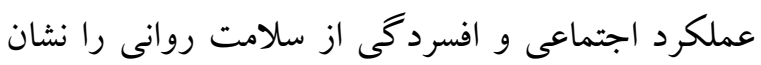

\begin{tabular}{|c|c|c|c|c|c|c|}
\hline 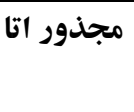 & 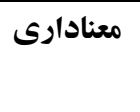 & آماره آزمون & مجانكين & آزادى درجه & مجذوروات & مؤلفههاى سلامت روان \\
\hline$\cdot / 49$ & $\cdot \cdot \cdot r$ & $\mid r / .1$ & $\wedge V / V q$ & 1 & $\Lambda V / V q$ & نشانههاى جسمانى \\
\hline$\cdot / 09$ &.$\cdots 1$ & YN/৭9 & rVG/Ar & 1 & TVG/AT & اضطر اب و بـ خوابى \\
\hline .191 &.$/ .1$ & $r Y / \cdot r$ & IYN/Yq & 1 & $\mid Y N / Y q$ & اختلال در عملكرد اجتماعى \\
\hline$\cdot|A|$ &.$/ .1$ & $r \Delta / . r$ & $\mid Y N / Y q$ & 1 & TKY/. T & افسردگى \\
\hline
\end{tabular}

استرس باعث افزايش ميزان افسردگى، اختلالات

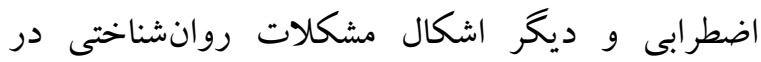
بيماران مبتلا به سرطان بِستان مىشود (لنكاجر، شلتون،

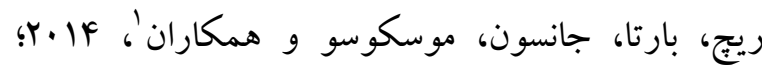
شايان و همكاران، هوسا). اضطراب و استرس مى تواند تأثير فيزيولوزيك مستقيم بر عملكرد سيستم ايمنى داشته باشد و با كاهش مقاومت بدن، فرد را مستعد تشديد بيمارى جسم و روان كند و از اين طريق مىتواند عملكرد روزمره و اجتماعى اين افراد را تحت تأثير قرار

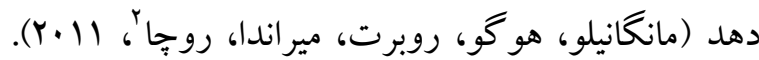
نتايج حاصل از تحليل كوواريانس درباره اثربخشى تمرينات تاى تى بر سلامت روان زنان مبتلا به سرطان

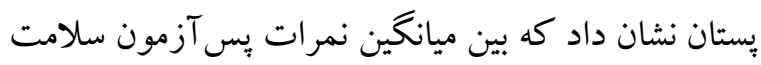
روان زنان مبتلا به سرطان بستان در گروه تمرينى و شاهد تفاوت معنادارى وجود دارد؛ بنابراين مىتوان نتيجه كيرى كرد كه ممكن است انجام تمرينات تاى بـى بر بهبود

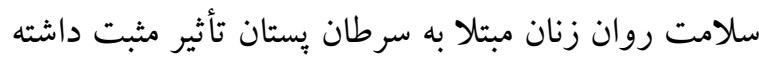
است. انجام تمرينات تاى جى باعث كاهش علائم

${ }^{1}$ - Lengacher, Shelton, Reich, Barta, Johnson-Mallard, Moscoso, et al.

2.- Manganiello A, Hoga LA, Reberte LM, Miranda CM, Rocha
همانطور كه جدول ب نشان مىدهد، تفاوت بين ميانخين نمرات سلامت روان در مرحلهى بس آزمون در دو گروه بـان

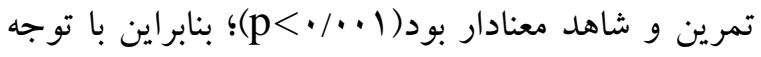
به جداول مىتوان نتيجه گرفت كه تمرينات تاىجى بر باني سلامت روان زنان مبتلا به سرطان بِستان مؤثر بوده است.

سرطان بستان در تمامى كثورها شايعترين تومور سرطانى در زنان محسوب مىشود، افراد مبتلا به سرطان بستان نسبت به ديخر مبتلايان مدت طولانى ترى با بيمارى و عوارض كوتاه مدت، بلند مدت و استرسهاى ناشى از آن زند سلامت روان اين گروه را تحت تأثير قرار دهد (بيرخائفى إنى

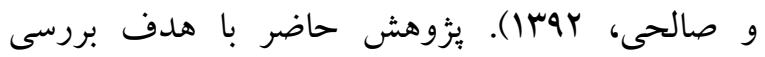
اثربخشى تمرينات تاى جى بر سلامت روان زنان مبتلا به سرطان بِتان، انجام شد. مطالعات مويد شيوع استرس و و اضطراب در بيماران مبتلا به سرطان بستان است كه مى تواند در اثر واكنشهاى روانشناختى به بيمارى و تأثير فيزيولوزيكك مستقيم خود سرطان بِتان و يا درمان دارويى باشد (شايان، خليلى، رهنورد و موسوى، هوسبا). 
بررسى دادههاى حاصل از تحقيق حاضر نشان داد كه انجام تمرينات تاى جى به طور معنىدارى از ميزان شكايت جسمانى زنان مبتلا به سرطان بستان كاسته است

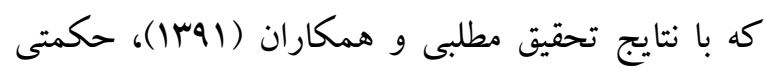

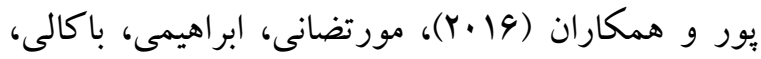

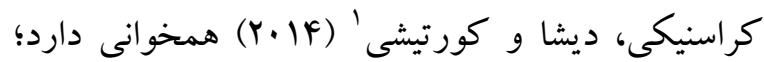
كه اين محققان در تحقيق خود به اين نتيجه رسيدند كه انجام تمرينات جسمانى باعث بهبود علائم جسمانى در

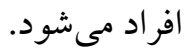

بررسى يافتهاى حاضر نشان داد كه انجام تمرينات تاى جيى به طور معنى دارى بر ميزان اضطراب و اختلال در

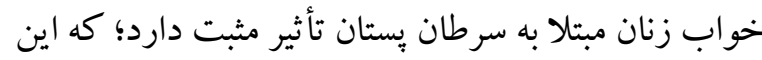

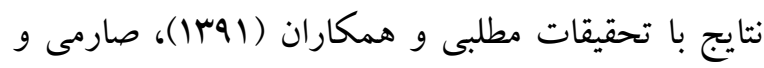

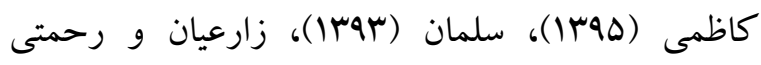

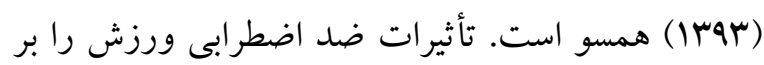
اساس سازو كار و كارهاى مختلفى مىتوان تبيين كرد كه از آن جمله مىتوان به ساز كارهاى زيست-فيزيولوزيك و روانى ورزش اشاره كرد. انجام تمرينات بدنى با تأثير بر

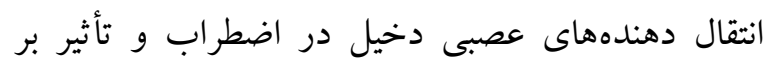
هورمونهاى استرس و كاهش تنش عضلانى ميزان اضطراب را كاهش مىدهد (مطلبى و همكاران، الوبا؛

ناظر، حسنى، ساردوئى، صيادى انارى، (9ז1). همجنين تمرينات تاى جيى به طور معنىدارى ميزان

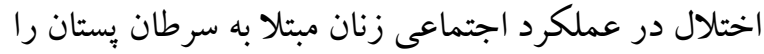
كاهش داد كه با نتايج صارمى و همكاران (ه (ه I))،

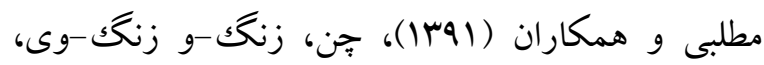

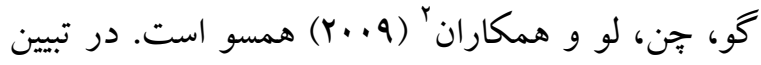
اين كاهش مىتوان جنين بيان كرد كه انجام تمرينات تاى

1- Murtezani, Ibraimi, Bakalli, Krasniqi, Disha, Kurtishi

${ }^{2}$ - Chen, Zheng Y, Zheng W, Gu, Chen, Lu, et al
جسمانى، اضطراب و بىخوابى، اختلال در عملكرد

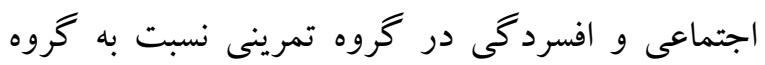
شاهد شد كه اين يافتها با نتايج روكك و همكاران (Y)

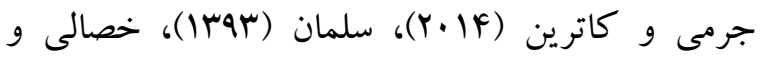

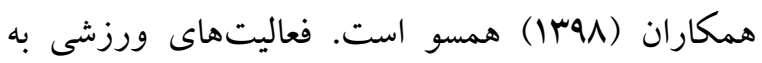
روشهاى مختلفى مىتو اند منجر به ارتقاى سلامت روان

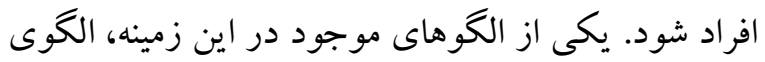

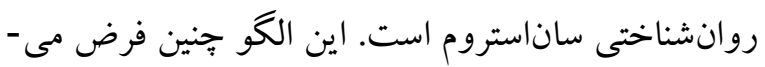
كند كه شركت در فعاليتهاى جسمانى منجر به افزايش عزت نفس فردى مى شود. بديهى است كه افزايش عزت نفس مىتواند در روابط بين فردى و شبكه اجتماعى

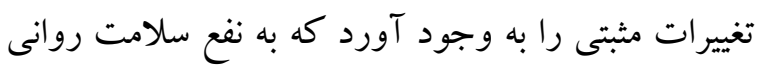

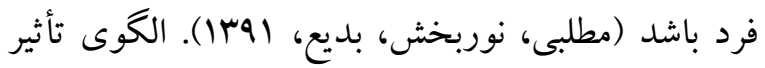

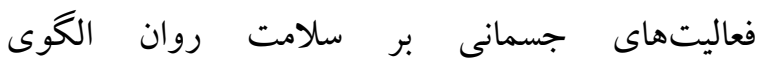
زيستشناختى است. در اين الكو كفته مىشود كه علت تأثير فعاليت بر سلامت روانى، تغييرات بيوشيميايى و

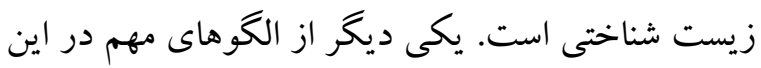
زمينه فرضيه حواسيرتى است. انجام فعاليتهاى جسمانى

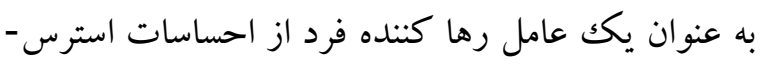
زاست كه اين امر باعث بهبود روانشناختى فرد مىشود.

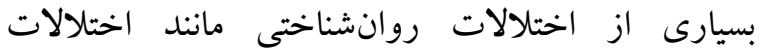
اضطر ابى و اختلالات خلقى مانند افسردگى و اختلال در

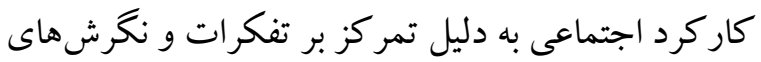
منفى است در نتيجه يكى از مداخلات روانشناختى اين است كه فرد را از تمر كز بر تفكرات منفى دور نكه دارد كه در اين زمينه فعاليتهاى ورزشى اين نقش را از طريق حواسيرتى به خوبى ايفا مى كنند (مطلبى و همكاران،

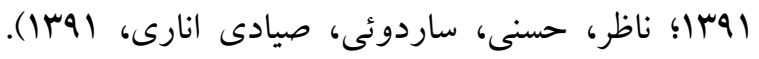


يكى از مداخلات شناختى و روانى به مربيان و بيماران، روانشناسان و مشاورانى كه به زنان مبتلا به سرطان يستان خدماترسانى مى كنند مىتواند در جهت بهبود سلامت روان آنها رهنمون سازد و از بسيارى از مشكلات آنها جلو گيرى كند؛ بنابر اين با توجه به نتايج يخوهش حاضر و نتايج ساير مطالعات بيشنهاد مىشود در برنامهريزىهاى بهداشتى و درمانى علاوه بر بررسى وضعيت روانى بيماران، مشاوره ورزشى، به عنوان بخشى از اقدامات معمول در كنار مداخلات طبى قرار گيرد و مطالعات كسترده و با تعداد بيشترى نمونه و مدت زمان طولانىترى در اين زمينه انجام گردد. از محدوديت هاى تحقيق حاضر مىتوان به كم بودن حجم نمونه و همجينين عدم همكارى برخى از بيماران به دلايل شخصى اشاره كرد.

\section{سياسگز ارى}

بدين وسيله بزوهشكر تحقيق حاضر، كمال تشكر و و

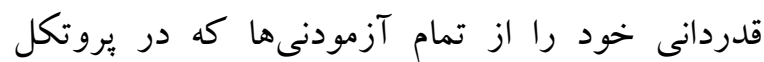
تمرينى شر كت كرده و با دقت تمام به يرسشنامه ها ياسخ

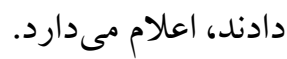

\section{References}

Agha-Alinejad H, Saei MA, Ramezani A. (2019). The Effect of Six Weeks' Interval Training on Tumor Volume and Adipose and Muscle Tissue Levels of Adiponectin and Leptin in Breast Cancer Bearing Female Mice. Exercise Physiology,10(40),17-32. (In Persian)

Audette J, Jin Y, Newcomer R, Stein L, Duncan G, Frontera W. (2006). Tai Chi versus brisk walking in elderly women. Age and Aging, 35,388-393.

Azimzadeh E, Hosseini M, Nourozi Tabrizi K. (2013). Effect of Tai Chi Chuan on Quality of Life in Women with Multiple Sclerosis. Hayat,
جى فرصت تعاملات اجتماعى را افزايش مىدهد و مهارتهاى اجتماعى را توسعه مىبخشد و به دليل ايجاد شبكهاى اجتماعى گستردهتر، سلامت روان فرد ارتقا مى يابد كه اين امر با افزايش عملكرد اجتماعى فرد همراه همجينين تمرينات تاىجى ميزان افسردگى در زنان مبتلا به سرطان يستان را به طور معنىدارى كاهش داد كه با نتايج تحقيقات صارمى و همكاران (ههب(1)، زارعيان و و همكاران (سوسا)، سلمان (rar|) همخوانى دارد. شواهد فيزيولوزيكى بسيارى دربارهى اثر ضد افسردگى تمرينات

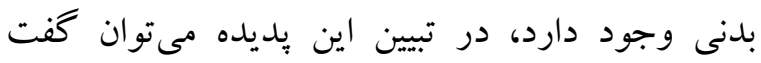
افزايش سطح سروتونين و نورايى نفرين در هنگام فعاليتهاى ورزشى موجب كاهش افسردگى مىشود؛ به عبارت ديخر، تمرينات بدنى از طريق رها شدن آندروفين و كاهش سطح كورتيزول در خون بر روح و روان انسان

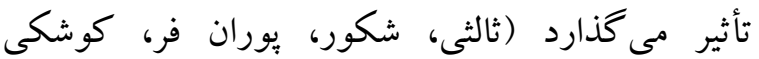

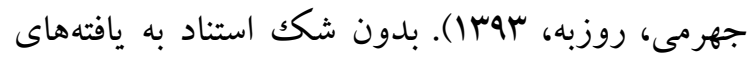
تحقيقاتى كه در زمينه فعاليتهاى مختلف جسمانى انجام شده است، مىتواند بسيار مؤثر باشد و بايد توجه به ورزش بانوان را به عنوان يكك استراتزى شفاف دنبال كنيم • بنابر اين، به نظر مىرسد، به منظور اثربخشى فعاليت ورزشى بر سلامت روان زنان مبتلا به سرطان يستان بايد اين تمرينات به صورت منظم در برنامه روزانه اين افراد طر احى شود.

\section{نتيجه كيرى}

با توجه به يافتهاى يزوهش حاضر مى توان نتيجه كرفت كه انجام تمرينات تاى جى باعث سلامت روان زنان مبتلا به سرطان يُتان مىشود. انجام تمرينات ورزشى به عنوان 
ه9 اثربخشى تمرينات تاى جى بر سلامت روان زنان مبتلا به سرطان بِستان

Journal of School of Nursing and Midwifery, Tehran University of Medical Sciences, 19(2), 1-13. (In Persian)

Campbell AV, Patel CC, Newton EJ, Jacobs SM. (2013). Gapstur, Associations of recreational physical activity and leisure time spent sitting with colorectal cancer survival, Journal of Clinical Oncolghy, 31,876-885.

Chen X, Zheng Y, Zheng W, Gu K, Chen Zh, Lu W, and et al. (2009). The effect of regular exercise on quality of life among breast cancer survivors. American Joumal of Epidemiol, 170(7):854-62.

Fontein DBY, Glas NA, Duijm M, Bastiaannet E, Portielje JEA, Van De Velde CJH, Liefers GJ. (2013). Age and the effect of physical activity on breast cancer survival: A systematic review. Cancer Treatment Reviews, 39(8),958-965.

Goldberg DP, Hillier VF. (1979). A scaled version of the general health questionnaire. Psychol med, 9(1):139-45.

Haghighat SH, Olfatbakhsh A, Sajadian As, Mehrdad N, Ansari M, Ebrahimi M, et al. (2013). Survival rate and related factors in breast cancer patients referred to the Breast Disease Center. Iranian Breast Diseases Journal, 6(3),28-36. (In Persian)

Hekmati Pour N, Hojjati H. (2016). Effects of Exercise on Mental Health of Elderly. Comprehensive nursing and midwifery,26(82):36-42. (In Persian)

Khesali Z, Mohammadi Shahboulaghi F, Khankeh H, Biglarian A. (2018). Eeffect of Tai Chi Chuan. on Anxiety among elderly women. Scientific Journal of Nursing, Midwifery and Paramedical Faculty, 3(4),15-23. (In Persian)

Lengacher CA, Shelton MM, Reich RR, Barta MK, Johnson-Mallard V, Moscoso MS, et al. (2014). Mindfulness based stress reduction (MBSR(BC)) in breast cancer: evaluating fear of recumence (FOR) as a mediator of psychological and physical symptoms in a randomized control trial (RCT). J Behav Med, 37(2),185-95.

Logghe IH, Verhagen AP, Rademaker AC, BiermaZeinstra SM, van Rossum E, Faber MJ.
(2010). The effects of Tai Chi on fall prevention, fear of falling and balance in older people: a metaanalysis. Prev Med,51(34),222-7.

Lynch DW, Dunstan JK, Vallance N. (2013). Owen, Don't take cancer sitting down, Cancer 1(19),1928-1935.

Macfarlen J, Kee M. (2005). Effect of Tai chi on the physical and psychological wellbeing of chiness older women. Joumal of Exercise Scinse Fitnes,3(2),87-94.

Manganiello A, Hoga LA, Reberte LM, Miranda CM, Rocha CA. (2011). Sexuality and quality of life of breast cancer patients post mastectomy. Europian Journal Oncol Nursing,15(2):16772.

Marandi SM, RezayatF, Asfarjani F, Rezaei Z. (2013). The effect of "Tai Chi" exercise on depression, quality of sleep and some of physiological factors in elderly, living in Nursing Home, 3(11),51-62. (In Persian)

Milne HM, Wallman KE, Gordon S, Coumeya KS. (2008). Impact of a combined resistance and aerobic exercise program on motivational variables in breast cancer survivors: a randomized controlled trial. Annals of behavioral medicine: a publication of the Society of Behavioral Medicine, 36(2):15866.

Motalebi L, Norbakhsh M, Badie A. (2012). Investigating the effect of participation in sports activities on students' mental health.Scientific-Research Journal, Sports Science Quarterly,4(9):114-134. (In Persian)

Murtezani A, Ibraimi Z, Bakalli A, Krasniqi S, Disha ED, Kurtishi I. (2014). The effect of aerobic exercise on quality of life among breast cancer survivors: A randomized controlled trial. Joumal of Cancer Research and Therapeutics, 10(3):658-64. (In Persian)

Nazer M, Hasani S, Sardoie GH, Sayadi Anari AR. (2012). The effectiveness of station designed sports on mental health of female teenagers. Health and Society,3(4),1-8. (In Persian)

Nomura T, Nagano K, Takato J, Ueki S, Matsuzaki Y, Yasumura S. (2011). The development of a 
Tai Chimexercise regimen for the prevention of conditions requiring long-term care in Japan. Arch Gerontol Geriatr, 52(3), 198-203.

Norouzian M, Rajabi H, Panahzadeh F. (2017). The Effect of 6 Weeks of Tai Chi Training on Cognitive Status, Dynamic Balance, and Quality of Life in Women with Stroke. Qom Univ Med Sci, 11(1),29-38. (In Persian)

Phillips Siobhan M, Kevin WD, Jeremy S, James C, Catherine M, McAuley E. (2015). Physical activity and sedentary behavior in breast cancer survivors: New insight into activity pattems and potential intervention targets. Gynecologic Oncology, 138(2),398-404.

Pirkhaefi A, Salehi F.(2014). Effectiveness of group semantics on women's mental health promotion Suffering from breast cancer. Health Psychology.2(4):61-69. (In Persian)

Rashidi M, Pournajaf A, Kazemi M, Keikhaweni S. (2019). Evaluating General Health Status using Goldberg's General Health Questionnaire among the Staff of Ilam University of Medical Sciences in (2015). Scientific Joumal of Ilam University of Medical Sciences,20(6),16-26. (InPersian)

Rock CL, Doyle C, Demark-Wahnefried W, Meyerhardt J, Coumeya KS, Schwartz AL, et al. (2012). Nutrition and physical activity guidelines for cancer survivors. CA A Cancer Joumal for clinicians, 62(4):243-74.

Salesi M, shakoor E, Pooranfar S, Koushkie Jahromi M, Roozbeh. (2014). The Effect of a selected exercise on, stress, anxiety and depression in kidney transplant patients. Pars Joumal of Medical Sciences, 12(3),31-38. (In Persian)

Salman Z (2015). The Relationship between Sport and Mental Health of Working Cultural Women. Journal of Educational Psychology, 9(33),113128. (In Persian)

Saremi A, Kazemi M. (2016). The effect of an aerobic training period on mental health and depression in Iranian women with polycystic ovary syndrome. Complementary Medicine Journal,1(18);1320-1331. (In Persian)

Shayan A, Khalili A, Rahnavardi M, Masoum SZ. (2016). The Relationship between Sexual
Function and Mental Health of Females with Breast Cancer. Scientific Joumal of Hamadan Nursing \& Midwifery Faculty, 24(3),220-228. (In Persian)

Smith RA, Brooks D, Cokkinides V, Saslow D, Brawley OW. (2019). Cancer screening in the United States, 2019: a review of current American Cancer Society guidelines, current issues in cancer screening, and new guidance on cervical cancer screening and lung cancer screening. Journal of CA Cancer Clinic, 69(2):184-210.

Zareian E, Rahmati F. (2014). The effect of aerobic exercise on anxiety, depression and quality of life Women with Breast Cance. Joumal of Clinical Psychology Studies,5(17);1-17. (In Persian) 